\title{
Opieka paliatywna sprawowana przez położną/pielęgniarkę nad noworodkiem z diagnoza wady letalnej (trisomia 22) - studium przypadku
}

\section{Palliative care provided by a midwife/nurse for a newborn with the diagnosis of lethal defect (trisomy 22) - case study}

Diana Sak, Anna Łozińska-Czerniak

Wydział Nauk o Zdrowiu, Warszawski Uniwersyłet Medyczny, Polska

\section{Streszczenie}

Wady rozwojowe mogą być poważnym zagrożeniem dla zdrowia płodu lub noworodka. Wiele z nich ma charakter letalny i wiąże się z dylematami moralnymi i etycznymi. Ważnym aspektem opieki nad nieuleczalnie chorym noworodkiem jest umiejętne ustalenie sytuacji, w której należy powstrzymać się od resuscytacji. Rozwój medycyny paliatywnej sprawił, że zmieniają się poglądy dotyczące prawidłowych zasad postępowania w przypadku noworodków urodzonych $\mathrm{z}$ wadą letalną. $W$ pracy omówiono opiekę paliatywną $\mathrm{w}$ grupie najmłodszych pacjentów na podstawie studium przypadku noworodka $\mathrm{z}$ diagnozą wady letalnej. Zwrócono uwagę na rolę personelu medycznego w zakresie opieki nad pacjentem oraz jego rodziną, podejmowanie kolejnych decyzji dotyczących procedur mających na celu zapewnienie noworodkowi możliwie najlepszego komfortu życia, a także na znaczącą potrzebę funkcjonowania hospicjów dziecięcych w Polsce. W omawianym przypadku opieka paliatywna zastosowana w opiece nad noworodkiem pomogła rodzicom zrozumieć diagnozę, pogodzić się z nieuchronną śmiercią dziecka i przebywać z nim we własnym domu pod opieką hospicjum.

Słowa klucze: medycyna paliatywna, noworodek, wada letalna.

\section{Abstract}

Developmental defects can be a serious threat to the health of the fetus or newborn. Many of them are lethal in nature and are associated with moral and ethical dilemmas. An important aspect of care for an terminally ill newborn is to skillfully determine the situation in which you should refrain from resuscitation. The development of palliative medicine has led to changing views on the proper management of newborn babies born with lethal defects. The paper discusses palliative care in the group of the youngest patients based on a case study of a newborn infant with diagnosis of lethal defect. The role of medical personnel in the care of the patient, making subsequent decisions on procedures to ensure the newborn receives the best possible quality of life and his family as well as the significant need for children's hospices in Poland are discussed. Palliative care used in caring for a newborn baby helped parents understand the diagnosis, get used to the inevitable death of a child and be with him in their own home under the care of the hospice.

Key words: palliative medicine, newborn, lethal defect.

\section{Adres do korespondencji:}

Dr Anna Łozińska-Czerniak, Warszawski Uniwersytet Medyczny, Wydział Nauk o Zdrowiu,

Warszawa, e-mail: anna.lozinska-czerniak@wum.edu.pl

\section{WSTĘP}

Za wadę letalną u płodu lub noworodka należy uznać zaburzenie rozwojowe prowadzące do poronienia samoistnego, porodu przedwczesnego lub zgo- nu wewnątrzmacicznego, zaburzenie rozwojowe prowadzące do przedwczesnej śmierci żywo urodzonego dziecka, bez względu na zastosowane leczenie, oraz zaburzenie rozwojowe zakwalifikowane do przerwania ciąży zgodnie z obowiązującą ustawą [1]. Wada 
letalna obejmuje ciężkie nieprawidłowości rozwojowe o niepewnym lub złym rokowaniu. Może prowadzić do poronienia obumarłego płodu, przedwczesnego urodzenia martwego dziecka lub śmierci dziecka bezpośrednio po urodzeniu lub we wczesnym okresie niemowlęcym bez względu na zastosowane leczenie [2].

Celem pracy było przedstawienie postępowania paliatywnego $\mathrm{w}$ opiece nad noworodkiem urodzonym $\mathrm{z}$ wadą letalną oraz zwrócenie uwagi na znaczenie opieki paliatywnej we współczesnej medycynie. Materiał zgromadzono na podstawie obserwacji oraz analizy dokumentacji medycznej. Obserwacja była prowadzona przez $30 \mathrm{dni}$, od chwili przyjęcia noworodka na Oddział Intensywnej Terapii Noworodka (OITN) do jego wypisu ze szpitala pod opiekę hospicjum domowego.

\section{OPIS PRZYPADKU}

Na OITN został przyjęty noworodek płci żeńskiej urodzony siłami natury w 37. tygodniu ciąży. Jego stan ogólny oceniono na średni, noworodek otrzymał 7-7-8-8 punktów w skali Apgar w kolejnych minutach życia, masa ciała wynosiła 1790 g, długość ciała $47 \mathrm{~cm}$, obwód głowy $29 \mathrm{~cm}$. Przebieg ciąży był prawidłowy, natomiast w 36. tygodniu ciąży wykryto hipotrofię płodu. Po urodzeniu w badaniu klinicznym u dziecka stwierdzono: hiperteloryzm, wąskie szpary powiekowe, spłaszczony nos, gotyckie podniebienie, podśluzówkowy rozszczep podniebienia, płetwiastą szyję, krótkie dłonie ze stożkowatymi palcami, a także niedrożność odbytu z towarzyszącą przetoką pochwową. Stwierdzono globalnie obniżone napięcie mięśniowe. Zabezpieczono krew w celu wykonania badań genetycznych. Ostatecznie uzyskano wynik badania metodą porównawczej hybrydyzacji genomowej (comparative genomic hybridization - CGH), który wykazał trisomię chromosomów 22 pary oraz duplikację długiego ramienia chromosomu X. Rozszerzenie diagnostyki o badanie kariotypu oraz badanie cytogenetyczne metodą FISH (fluorescent in situ hybridization) potwierdziło rozpoznanie. Wymienione wady uznano za letalne, co zostało potwierdzone opinią genetyków.

Po urodzeniu dziecko pozostawało na oddechu własnym z tlenoterapią bierną, następnie, ze względu na zabieg chirurgiczny w celu wyłonienia sztucznego odbytu, zostało zaintubowane i włączone w cykl wentylacji SIMV (synchronized intermittent mandatory ventilation). W celu sedacji i analgezji zastosowano fentanyl. Okres pooperacyjny był powikłany niewydolnością krążenia. Po zabiegu chirurgicznym, ze względu na bradykardię i hipotensję, do leczenia włączono Dobutrex. Następnie noworodek pozostawał wydolny krążeniowo. Po planowej ekstubacji pozostawiono noworodka na oddechu włas- nym z okresową tlenoterapią bierną pod kontrolą saturacji. Początkowo prowadzono całkowite żywienie pozajelitowe, następnie częściowe żywienie pozajelitowe drogą wkłucia centralnego. Ostatecznie noworodek był karmiony wyłącznie drogą enteralną przez sondę dożołądkową pokarmem matki.

$\mathrm{Z}$ powodu niedokrwistości wykonano dwukrotnie transfuzje uzupełniające koncentratu krwinek czerwonych. Ze względu na wzrost wykładników stanu zapalnego (Staphylococcus epidermidis) w posiewie krwi wdrożono antybiotykoterapię (Tazocin i Amikin, następnie Meronem i Wankomycyna). Po zastosowanym leczeniu nie stwierdzono wzrostu bakterii. W przebiegu infekcji obserwowano pogorszenie tolerancji karmień, wstrzymano podaż enteralną i ponownie stosowano całkowite żywienie pozajelitowe drogą wkłucia centralnego, po czym powrócono do karmienia enteralnego. Kilkakrotnie podjęto próby karmienia smokiem, jednak ze względu na wąskie szpary nosowe utrudniające oddychanie zakończyły się one niepowodzeniem.

W celu złagodzenia bólu noworodkowi podawano leki przeciwbólowe zgodnie ze zleceniem lekarskim. Personel medyczny monitorował i oceniał natężenie bólu u dziecka poprzez obserwację jego zachowania zgodnie ze skalami FLACC (ang. Face, Legs, Activity, Cry i Consolability) i COMFORT obejmującą ocenę czynności serca i ciśnienia tętniczego krwi. Stosowano również niefarmakologiczne sposoby mające na celu uśmierzenie bólu. Otulano noworodka w rogalu za pomocą kocyka w wygodnej dla niego pozycji. Stosowano metodę Facilitated Tucking (FT) polegającą na przytrzymaniu ramion i kończyn dolnych dziecka w przygiętej pozycji, blisko tułowia, tak aby uzyskać pozycję płodową. Wprowadzono ssanie nieodżywcze z użyciem smoczka, a także doustną podaż 30\% glukozy na przednią część języka około dwóch minut przed wykonaniem takich zabiegów, jak np. kaniulacja naczyń. Stosowano preparaty do usuwania samoprzylepnych opatrunków w celu łagodzenia dolegliwości bólowych oraz ochrony niedojrzałej skóry przed uszkodzeniem. Zachowywano szczególną ostrożność i delikatność podczas wykonywanych procedur oraz ograniczano zabiegi lecznicze do niezbędnego minimum zgodnie z zasadą minimal handling [3], a także przestrzegano zasad paliatywnej opieki podstawowej, której głównym założeniem jest zapewnienie dziecku komfortu cieplnego, delikatnej i troskliwej opieki oraz spokoju [4].

W celu zmniejszenia ryzyka powstania odleżyn zmieniano ułożenie dziecka $\mathrm{w}$ rogalu oraz umiejscowienia czujnika kardiomonitora średnio co 3 godziny. Starano się synchronizować wykonywane procedury z rytmem snu i czuwania. Aby zmniejszyć obawy rodziców związane z wykonywaniem czynności pielęgnacyjnych $u$ noworodka, przeprowadzono $\mathrm{z}$ nimi rozmowy na temat odpowiedniej 
pielęgnacji oraz poinstruowano, w jaki sposób należy wykonywać toaletę dziecka. Rodzice początkowo mieli poczucie niejasności własnej roli $\mathrm{w}$ procesie opiekuńczym, dlatego położne i pielęgniarki wielokrotnie rozmawiały z rodzicami o znaczeniu ich obecności przy dziecku i bezpośredniego kontaktu, zachęcały do kangurowania oraz do wspólnej pielęgnacji noworodka.

Rodzice mieli trudności w akceptacji nieuleczalnej choroby dziecka, zapewniono im konsultację psychologiczną. Wyjaśniono, jakie są konsekwencje zdrowotne wynikające z postawionej diagnozy. Przedstawiono rodzicom plan dalszego postępowania mającego na celu zapewnienie noworodkowi możliwie najlepszego komfortu życia. Początkowo zaproponowano dalsze prowadzenie nieinwazyjnego wsparcia oddechowego, przetaczanie preparatów krwiopochodnych, żywienie parenteralne, antybiotykoterapię oraz leczenie przeciwbólowe. Po konsultacji ze specjalistami w dziedzinie medycyny paliatywnej podjęto jednak decyzje lecznicze zapewniające minimalną ingerencję farmakologiczną, ograniczającą się do leczenia przeciwbólowego. Zaproponowano pomoc w podjęciu współpracy z dziecięcym hospicjum domowym, wskazując na bezcelowość dalszej hospitalizacji. Założono kartę podsumowującą dyskusję nad opieką paliatywną, obowiązującą w placówce jako formalny protokół wewnętrzny. W karcie zawarto podjęte decyzje będące podsumowaniem dyskusji, stanowisko rodziców i zgłaszane prośby. Stanowisko rodziców było cytowane. Opinie lekarskie i pielęgniarskie były zgodne. Protokół został podpisany przez zespół medyczny i rodziców. Decyzję o ograniczeniu terapii daremnej podjął zespół składający się z dwóch lekarzy neonatologów, anestezjologa oraz ordynatora OITN. Zespół medyczny przeprowadził długą rozmowę $\mathrm{z}$ rodzicami $\mathrm{w}$ obecności psychologa, wyjaśniając możliwy scenariusz przebiegu leczenia, uwzględniający infekcję z pogarszaniem stanu ogólnego spowodowaną wrodzonym niedoborem odporności. Ustalono z rodzicami, że w przypadku zatrzymania krążenia i oddychania $\mathrm{u}$ ich dziecka nie będą podejmowane czynności resuscytacyjne. Rodzice zaakceptowali plan postępowania. Mama dziewczynki wyraziła prośbę, aby mogła przebywać z dzieckiem od wczesnych godzin porannych oraz przeniesienia dziewczynki do izolatki i możliwości odwiedzin dziadków. Poprosiła również o kontynuowanie monitorowania parametrów bólowych, które było wprowadzone po zabiegu chirurgicznym. Stwierdziła, że powoli zaczyna godzić się ze śmiertelną chorobą dziecka.

Po miesięcznej hospitalizacji dziewczynka została wypisana do domu w stanie ogólnym średnim pod opiekę hospicjum domowego.
DYSKUSJA

Postępowaniem w przypadku zdiagnozowania wady letalnej może i powinna być opieka paliatywna. Niejednokrotnie rodzice ze względu na swój światopogląd mają wątpliwości dotyczące dostępnych wariantów dalszego postępowania, nie chcą przerywać ciąży pomimo zdiagnozowania nieuleczalnej choroby u dziecka. Często taka postawa spotyka się z niezrozumieniem ze strony lekarzy ginekologów, traktowana jest jako wyraz ich zacofania i braku nowoczesności w podejmowaniu decyzji. Wielu z nich nie przyjmuje do wiadomości, że urodzenie dziecka i pożegnanie się z nim jest dla tych rodzin pożądanym i najlepszym rozwiązaniem [5]. $\mathrm{W}$ opisywanym przypadku, dzięki zastosowanej opiece paliatywnej, rodzice mieli czas na to, aby zrozumieć niepomyślną diagnozę, oswoić się z sytuacją oraz być razem $z$ dzieckiem we własnym domu pod specjalistyczną opieką hospicjum. Stała obecność rodziców zapewniła dziecku potrzebę bliskości.

Często zdarza się, że wady letalne rozpoznawane są dopiero pod koniec prawidłowo przebiegającej i rozwijającej się ciąży, gdy zgodnie z polskim prawem nie można przeprowadzić aborcji. Opisywana dziewczynka jest przykładem rozpoznania wady letalnej po urodzeniu. Hipotrofię płodu rozpoznano w 36. tygodniu ciąży i dopiero wówczas podjęto intensywną obserwację matki. Badania genetyczne potwierdzające letalność wady zostały wykonane po urodzeniu dziecka. Niezmiernie ważne jest, aby personel medyczny rozumiał sytuację i oczekiwania rodziców, którzy dopiero po urodzeniu dziecka dowiadują się o diagnozie. Francuskie Stowarzyszenie SPAMA (Soins Palliatifs et Accompagnement en Maternite), zajmujące się wspieraniem rodziców w momencie nadchodzącej śmierci ich dziecka spowodowanej chorobą letalną, określiło potrzeby rodziców w czasie opieki nad dzieckiem nieuleczalnie chorym. Według specjalistów istotną rolę pełni wówczas wsparcie emocjonalne w momencie przekazania diagnozy oraz cierpliwość w oczekiwaniu na podjęcie przez rodziców decyzji, przedstawienie ich stanowiska i oczekiwań. Ważne jest także rzetelne przedstawienie sytuacji klinicznej dziecka i sposobu prowadzenia opieki paliatywnej. Wielu rodziców przechodzących przez okołoporodowy okres żałoby podkreśla, że znaczące jest umożliwienie im kontaktu z dzieckiem, nawet na krótką chwilę, aby mogli poczuć się rodzicami oraz umożliwienie obecności pozostałych członków rodziny, która jest nieodłącznym elementem wsparcia. Personel medyczny zajmujący się taką rodziną pełni także znaczącą rolę poprzez towarzyszenie rodzicom oraz wsparcie emocjonalne w pierwszych dniach żałoby [6].

Bardzo często diagnoza wady letalnej jest dla rodziców abstrakcją. Reakcją obronną jest negowa- 
nie faktu, że ich dziecko jest nieuleczalnie chore. Niejednokrotnie $\mathrm{w}$ pierwszej chwili nie są $\mathrm{w}$ stanie pojąć tego, co się stało i co oznacza postawiona diagnoza, dlatego ważne jest, aby informacje były przekazywane w sposób konkretny i jasny [7]. Decyzja rodziców wyznających zasadę pro-life nie powinna jednoznacznie określać ich zgody na resuscytację, intensywną terapię czy leczenie chirurgiczne noworodka. Nie powinna być także interpretowana w ten sposób przez lekarzy ze względu na właściwą opiekę nad pacjentem nieuleczalnie chorym. W przypadku omawianego dziecka wszelkie działania chirurgiczne motywowane były zapobieganiem cierpieniu związanym $\mathrm{z}$ nieprawidłowym funkcjonowaniem układu pokarmowego.

Zgodnie z Rozporządzeniem Ministra Zdrowia z dnia 29 października 2013 r. w sprawie świadczeń gwarantowanych z zakresu opieki paliatywnej i hospicyjnej, które weszło w życie 10 lutego 2017 r., do świadczeń gwarantowanych $\mathrm{w}$ opiece paliatywnej należą porady i konsultacje lekarskie, porady psychologa $\mathrm{w}$ poradni medycyny paliatywnej lub hospicjum, koordynacja opieki przez zapewnienie współpracy $\mathrm{z}$ podmiotami udzielającymi kobiecie świadczeń z zakresu położnictwa, ginekologii i neonatologii (z hospicjum, jeśli będzie istniała konieczność wypisania dziecka ze szpitala w celu zapewnienia ciągłości opieki, z ośrodkami diagnostyki prenatalnej), poinformowanie rodziców o możliwości pożegnania się ze zmarlym dzieckiem oraz o sposobie pochówku, a także wyjaśnienie im postępowania $w$ przypadku zgonu dziecka oraz wsparcie w żałobie po śmierci dziecka, również przez udział $\mathrm{w}$ grupie wsparcia [8]. Zgodnie $\mathrm{z}$ wyżej wymienionym rozporządzeniem rodzice dziewczynki na bieżąco byli informowani o stanie zdrowia dziecka przez specjalistów oraz uczestniczyli w konsultacjach dotyczących dalszego postępowania. Ze względu na trudności $w$ akceptacji choroby mama korzystała również z opieki psychologa.

Ważnym aspektem $\mathrm{w}$ opiece nad noworodkiem nieuleczalnie chorym jest umiejętne stwierdzenie sytuacji, w której należy powstrzymać się od resuscytacji oraz uporczywego leczenia podtrzymującego życie. Na podstawie badania przeprowadzonego w 2016 r. na grupie 76 pracowników Kliniki Intensywnej Terapii Instytutu „Pomnik - Centrum Zdrowia Dziecka", w którym analizowano poziom wiedzy i postaw personelu wobec prowadzenia uporczywej terapii u dzieci, można zaobserwować, że jednoznaczne zdefiniowanie pojęć „uporczywa terapia" oraz "godna śmierć" jest niezmiernie trudne. Codzienne spotykanie się ze śmiercią $\mathrm{w}$ pracy zawodowej może także negatywnie wpływać na zdrowie psychiczne, życie prywatne i wypalenie zawodowe pracowników ochrony zdrowia, co znacząco przekłada się na jakość świadczonej opieki.
Zdecydowana większość personelu stwierdziła, że pacjent powinien mieć prawo do rezygnacji z uporczywej terapii. Pracownicy medyczni objęci badaniem twierdzili również, że podejmowanie decyzji o zaprzestaniu leczenia nie wpływa na jakość i rodzaj świadczonej opieki. Ankietowani zapytani o to, kto może podjąć decyzję o zaprzestaniu uporczywego leczenia, wskazali głównie na pacjenta, następnie jego rodzinę oraz lekarza. Ważnym, wskazanym przez badanych członkiem zespołu terapeutycznego, niezbędnym we wspieraniu zarówno rodziców, jak i personelu medycznego okazał się psycholog [9]. Powyższe badanie wskazuje, że wycofanie się z uporczywego leczenia jest bardzo trudne. Ciężko jest jednoznacznie określić, kto powinien odpowiadać za podejmowanie niniejszej decyzji. Bardzo ważna jest także rozmowa z psychologiem zarówno ze strony rodziny, jak i osób sprawujących opiekę nad pacjentem, aby była ona na jak najwyższym poziomie. Przedstawiona w pracy dziewczynka była hospitalizowana w placówce bazującej na aktualnych standardach postępowania z pacjentami nieuleczalnie chorymi. Decyzja o wdrożeniu opieki paliatywnej ze względu na diagnozę wady letalnej spowodowała ostateczne odstąpienie od uporczywego leczenia. Początkowo stosowano wentylację mechaniczną, przetaczanie preparatów krwiopochodnych oraz żywienie parenteralne. Dopiero po uzyskaniu wyników badań genetycznych i opinii genetyków stwierdzono, że zdiagnozowana wada nie daje dziecku szans na przeżycie i podjęto współpracę z hospicjum. Działalność hospicjów domowych odgrywa kluczową rolę $\mathrm{w}$ opiece nad dziećmi oraz ich rodzinami, które spotkały się z diagnozą wady letalnej. Podjęcie przez szpital współpracy z hospicjum po stwierdzeniu bezcelowości dalszej hospitalizacji wskazuje także na wzrastające zapotrzebowanie na działalność hospicjów domowych oraz może świadczyć o stopniowej zmianie postępowania personelu medycznego na rzecz opieki paliatywnej.

Warto zwrócić również uwagę na dane epidemiologiczne dotyczące przyczyn zgonów dzieci w Polsce, z których wynika, że najczęstszą przyczyną śmierci noworodków i niemowląt są zaburzenia okresu okołoporodowego powstające w trakcie ciąży oraz w pierwszych 6 dniach życia noworodka, wady rozwojowe wrodzone, które stanowią 37\% zgonów, oraz choroby nabyte $w$ okresie niemowlęcym lub urazy. W latach 2010-2018 współczynnik zgonów niemowląt na 1000 żywych urodzeń wahał się pomiędzy 5 a 3,8, co wskazuje na tendencję malejącą. Obniżanie się poziomu umieralności niemowląt, a także stosunkowo niska liczba urodzeń martwych skutkują spadkiem natężenia umieralności okołoporodowej, której współczynnik wynosi obecnie ok. 5,3\%o, wobec 19,5\%o w 1990 r. W 2016 r. liczba najliczniejszych zgonów związanych ze stanem 
rozpoczynającym się w okresie okołoporodowym wynosiła 831. Kolejna grupa, którą stanowiły wady rozwojowe wrodzone, odnotowała 682 zgonów. Nieco mniej liczne były zgony wynikające $\mathrm{z}$ przyczyn zewnętrznych, których liczba wynosiła 621. Zdecydowanie rzadsze były zgony związane z chorobami układu moczowo-płciowego, chorobami układu trawiennego czy chorobami zakaźnymi i inwazyjnymi [10]. Z powyższych statystyk wynika, że zgony spowodowane przez wrodzone wady rozwojowe stanowią dużą grupę, dlatego niezmiernie ważne jest, aby edukować personel medyczny w zakresie medycyny paliatywnej, tak aby spowodować wzrost świadomości wśród pracowników ochrony zdrowia oraz wspierać rozwój hospicjów zarówno stacjonarnych, jak i domowych, do których trafia coraz większa liczba noworodków, u których zdiagnozowano nieuleczalną wadę wrodzoną.

Irlandzka służba zdrowia opublikowała w 2016 r. zestaw krajowych standardów opieki nad rodziną, w której doszło do utraty ciąży i śmierci okołoporodowej. Zgodnie z powyższymi standardami każde dziecko powinno otrzymać wysokiej jakości opiekę paliatywną, a jego rodzice wsparcie ze strony psychologa według ich potrzeb [11]. Europejskie normy postępowania znalazły zastosowanie także w trakcie opieki nad opisywanym noworodkiem i jego rodziną. Noworodek otrzymał specjalistyczną opiekę, natomiast rodzice zostali objęci opieką psychologa, a także skierowani na badania genetyczne.

Zgodnie z raportem Europejskiego Towarzystwa Opieki Paliatywnej (European Association for Palliative Care-EAPC) w celu ujednolicenia norm obowiązujących podczas opieki nad pacjentem $\mathrm{z}$ chorobą letalną $\mathrm{w}$ tworzeniu europejskiego standardu wzięło udział 35 przedstawicieli towarzystw hospicyjnych i opieki paliatywnej z 22 krajów. Pomimo kulturowych różnic dotyczących opieki paliatywnej w Europie EAPC zaproponowało wspólną definicję, która miała jednoczący wpływ na organizację opieki paliatywnej w wielu krajach. „Opieka paliatywna jest aktywną, pełną opieką nad chorym, którego choroba nie odpowiada na leczenie. Kontrola bólu i innych objawów oraz problemów socjalnych, psychologicznych i duchowych jest nadrzędna. Opieka paliatywna jest interdyscyplinarna, a jej zakres obejmuje chorego, jego rodzinę i społeczność. W pewnym sensie opieka paliatywna ma za zadanie zapewnić najbardziej podstawową pomoc, to znaczy zaspokajać potrzeby chorego gdziekolwiek tego wymaga - w domu lub w szpitalu. Opieka paliatywna docenia jakość życia. Umieranie to normalne zjawisko, śmierci nie należy przyspieszać ani opóźniać. Opieka jest ustanowiona po to, by zapewnić najlepszą możliwą jakość życia aż do śmierci" [12]. Zgodnie z tą definicją opieka sprawowana nad dziewczynką spełniała zarówno normy polskie, jak i europejskie.
Bardzo ważnym aspektem opieki nad rodziną, którą dotknęła diagnoza nieuleczalnej choroby u dziecka, jest także idea hospicjów perinatalnych, które proponują inne sposoby poradzenia sobie z nową sytuacją niż terminacja ciąży. Kluczową rolę $\mathrm{w}$ opiece pełni $\mathrm{w}$ takim przypadku psycholog. Niepokojąca diagnoza w czasie ciąży jest dla rodziców źródłem lęku o dalsze losy dziecka, dlatego właśnie rozmowa $z$ psychologiem stanowi ważny element w zrozumieniu sytuacji oraz komunikatów ze strony lekarzy. Wraz z propozycją hospicyjnej opieki perinatalnej rodzice dostają szansę świadomego wyboru dalszego postępowania $\mathrm{z}$ ich nieuleczalnie chorym dzieckiem. Wybierając opiekę hospicyjną, dają sobie czas na oswojenie się z sytuacją oraz możliwość przygotowania się do żałoby w sytuacji, kiedy istnieje duże zagrożenie, że dziecko umrze tuż po urodzeniu. Opieka paliatywna nie jest jednak tylko dawaniem czasu rodzicom na oswojenie rzeczywistości. Jest ona najlepszym rozwiązaniem dla dobra dziecka, poszanowania jego życia i godności. Szeroko pojęta opieka nad przewlekle oraz nieuleczalnie chorym ma na celu poprawę jego funkcjonowania i uśmierzenie bólu z wykorzystaniem nowoczesnych technik i coraz to nowszych form terapii. Nasze "społeczeństwo życia” w pogoni za nowoczesnością często jednak zapomina o drugim aspekcie - uldze w cierpieniu oraz właściwej opiece w czasie umierania [13].

\section{WNIOSKI}

Opieka paliatywna jest stale rozwijającą się dziedziną medycyny, przynoszącą nowe dylematy moralne i etyczne zarówno dla personelu medycznego, jak i rodziców, których nowo narodzone dziecko cierpi na śmiertelną chorobę. Często trudno jest podjąć decyzję o jej zastosowaniu ze względu na dużą odpowiedzialność za utrzymanie życia za wszelką cenę oraz towarzyszące emocje rodzin. Zastosowana $\mathrm{w}$ opiece nad noworodkiem opieka paliatywna pomogła rodzicom zrozumieć niepomyślną diagnozę, oswoić się z nieuniknioną śmiercią ich dziecka oraz być z nim we własnym domu pod opieką hospicjum, zapewniając mu poczucie bezpieczeństwa.

Autorki deklarują brak konfliktu interesów.

\section{PIŚMIENNICTWO}

1. Dangel T. Wady letalne u płodów i noworodków opieka paliatywna jako alternatywa wobec eugenicznej aborcji, eugenicznego dzieciobójstwa i uporczywej terapii. W: Opieka paliatywna nad dziećmi. Dangel T (red.). Fundacja Warszawskie Hospicjum dla Dzieci, Warszawa 2008; 17-24. 
2. Krzeszowiak J, Śmigiel R. Rola i zadania położnej jako członka zespołu sprawującego opiekę nad ciężarną pacjentką z rozpoznaną wadą letalną u płodu. Piel Zdr Publ 2016; 6: 57-61.

3. Pilewska-Kozak A. Organizacja oddziału intensywnej opieki neonatologicznej. OPM 2012; 11: 12-16.

4. Kuć D. Co robić, kiedy „nie da się nic zrobić” - opieka nad człowiekiem umierajacym. Med Prakt 2016; 5: 113-115.

5. Szymkiewicz-Dangel J. Perinatalna opieka paliatywna - czy możliwa jest wspólpraca położników i neonatologów z hospicjami domowymi dla dzieci? W: Opieka paliatywna nad dziećmi. Dangel T (red.). Fundacja Warszawskie Hospicjum dla Dzieci, Warszawa 2007; 25-28.

6. Rutkowska M. Etyka w medycynie perinatalnej na świecie i w Polsce. W: Postępowanie paliatywne $\mathrm{w}$ opiece perinatalnej. Rutkowska M, Szczepański W (red.). Wydawnictwo Lekarskie PZWL, Warszawa 2018; 17-35.

7. Wawrzyniak-Łuczak J. Diagnostyka prenatalna - analiza celu badania z perspektywy lekarza, matki/rodziców, płodu/dziecka. Perinatol Neonatol Ginekol 2013; 6: 7-13.

8. Rozporządzenie Ministra zdrowia z dnia 31 stycznia 2017 roku zmieniające rozporządzenie $w$ sprawie świadczeń gwarantowanych $\mathrm{z}$ zakresu opieki paliatywnej i hospicyjnej, Dz.U. 2017 poz. 236.

9. Januszewska A, Zarzeka A, Iwanow L i wsp. Próba analizy poziomu wiedzy i postaw pracowników Kliniki Intensywnej Terapii Instytutu „Pomnika - Centrum Zdrowia Dziecka” wobec prowadzenia uporczywej terapii u dzieci. Pielęg Pol 2016; 3: 389-396.

10. Umieralność i zgony dzieci. Stowarzyszenie Polski Komitet Narodowy UNICEF, 2018. Dostępne na:

11. https://www.dzieciwpolsce.pl/analiza/12/umieralnosc-i-zgony-dzieci

12. McMahon DL, Twomey M, O'Reilly M. i wsp. Referrals to a perinatal specialist palliative care consult service in Ireland. Arch Dis Child Fetal Neonatal Ed 2018; 103: 573-576.

13. Raport dotyczący standardów i norm dla opieki hospicyjnej i paliatywnej w Europie: część 1 . Zalecenia Europejskiego Towarzystwa Opieki Paliatywnej. Med Paliat Prakt 2010; 4: 41-53.

14. Buss T, Lichodziejewska-Niemierko M. Opieka paliatywna w Polsce - od idei do praktyki. Forum Med Rodz 2008; 2, 4: 277-285. 